\begin{tabular}{c} 
Journal of Business School \\
$2019,2(3): 63-82$ \\
DOI: $10.26677 / \mathrm{TR} 1010.2019 .79$ \\
\hline \\
Journal Homepage: $\mathrm{https://www.journalbusiness.org}$ \\
\hline
\end{tabular}

\title{
Application and implications of Maslow's Hierarchy of Needs Theory: The Zimbabwean experience
}

\author{
Promise Zvavahera (PhD) \\ Reformed Church University, Faculty of Commerce, Zimbabwe. \\ promisezvavahera59@gmail.com
}

\author{
Roselyn Tandi \\ Catholic University of Zimbabwe, Faculty of Commerce.rtandi@cuz.ac.zw
}

\begin{abstract}
This study was carried out to evaluate the relevance of Maslow's Hierarchy of Needs Theory in satisfying the needs of teachers in a rural setup. A qualitative approach was taken focusing on Mazowe District. It was found that even though, Maslow's theory forms the basis for motivation strategies in organisations, it was inconsistent with the local and best human capital practices. The findings pointed to the fact that there were violations of basic, safety, esteem and self-actualisation needs by the employer. It also emerged that the District was politically charged during and soon after harmonised general elections and the most affected were teachers due to their freedom of expression and as disseminators of information and knowledge in communities they serve. Self-actualisation was found to be a myth since the employer failed to meet basic needs. The study recommended that motivation should be localised considering the factors that have impact on motivation of employees. Theories of motivation can therefore be not viewed as a universal construct as obtained in this study.
\end{abstract}

Keywords: motivation productivity, needs, retention

\section{Introduction}

The Public Service Commission (PSC) which is the employer of all civil servants teachers included, has tried a number of motivation and retention strategies since independence in 1980. Payment of a bonus, rural and transport allowances among others have been tried and failed to yield the desired results. A number of studies have been carried out on teacher motivation but few studies have been conducted in Zimbabwe, especially looking at rural teachers (Belle, 2007; Chindanya, 2002). Paramount to the survival of institutions or organisations is the motivation and job satisfaction of its workforce. According to Cole (2009), organisations have the responsibility of creating enabling environments for their employees to be productive and motivated. Employees should be given the opportunity to exercise self-control and be responsible for their actions. Giving employees autonomous in their jobs is great motivation in itself (Ployhart and Moliterno, 2011). Organisations need to recognise individual efforts and 
offer appropriate rewards. It is also critical for organisations to nurture and retain hard working and committed pools of employees. The intellect of human is the most important resource and an organisation depends on people for its existence and profitability (Chin and Sofian, 2011). The Public Service Commission has failed to motivate and retain qualified and experienced personnel leading to poor service delivery (Zvavahera, 2015). This study sought to evaluate the applications and implications of Maslow's Hierarchy of Needs Theory from the Zimbabwean perspective.

\section{Literature}

Motivation and retention are topical issues in modern organisations around the globe. Motivation is defined as the force that prompts action in a positive direction with the view of achieving agreed objectives (Maicibi, 2004). Motivation also refers to all forms of forces that are positive and shown in employees through the achievement of organisational and individual goals concurrently (Cole, 2009). On the other hand, employee retention is defined as the ability by an organisation to retain its staff in the face of competition (Ongori, 2007). Management through modern management practices can motivate and retain employees. Employees who are engaged in organisations come from different backgrounds such as the old and the young, male and female married and unmarried. This is how complex the environment is. Gannon (1985) states that it is the responsibility of management to make sure that motivation strategies cover a wide spectrum of employees in order for them to be effective and acceptable. Mukokoma (2008) feels that there are no motivation strategies that can be effectively applied throughout all organisations due to the external environment that is difficult to control.

Factors that motivate employees in certain environments cannot be overemphasized as these might fail in other areas. According to Lumley, Coetzee, Tladinyane and Ferreira (2011), retention and motivation are becoming a challenge since employees and labour laws are increasingly becoming demanding and more complex on a daily basis. Job satisfaction is influenced by working conditions (Hosseini, 2013). Lumley et al. (2011) acknowledge that job satisfaction leads to improved productivity and profitability for the organisation. Motivated and committed employees are crucial for the success and survival of organisations (Maicibi, 2004). According to Cole (2009), Taylor had an assumption that employees were motivated by high salaries and this notion was however, refuted by Herzberg (1959) in his "Two Factor Motivation Theory". Maicibi (2004) further discovered that management should be concerned with the creation, development and maintenance of an environment to which individuals work together in groups towards the accomplishment of common organisational goals and objectives. To this end, an organisation cannot effectively and efficiently achieve its mission without motivating and retaining its personnel to work together towards the achievement of set goals and objectives (Cole, 2004).

Organisations aim to create productive workforces, reduce absenteeism and labour turnover (Wright and McMahan, 2011). Self-actualisation is critical for sustenance and growth of organisations and individual employees. Blunt and Jones (1992) aver that satisfaction of workers is central to the proper management of employees which translates to improved motivation and productivity. Cole (2004) found out that employees come to work for various reasons. Some come to work as a means of survival, whilst others seek growth, self-esteem and satisfaction in their careers. However, individuals in organisations are motivated by various things such as the job itself or challenging tasks (Chin and Sofian, 2011). The above issues bring us to the understanding that the management of employees at the workplace is complex since there are many variables that affect their performance. Wright and McMahan (2011) argued that organisations should consider their employees as a source of competitive 
advantage since it is the only resource which cannot be imitated by competition. As submitted by Lumleyet al. (2011) most rural schools' teachers are affected by a variety of challenges emanating from political, socio-economic, legal, and technological environments. According to a study carried out in Rawalpindi City in 2004, in the United States of America by the US Government, teachers were found to be the role models of their school children in shaping their future careers. This means that if teachers are not happy, this is likely to affect the performance of the children leading to poor results. Teachers therefore, play a critical role in their learning and in shaping the children's future careers.

It is critical to understand that motivation leads to acceptable behaviours which are likely to produce the desired outcome. When a person is motivated, he/she tries to achieve both individual and organisational goals. For an individual to perform to the satisfactory level, environmental factors (political, economic, social, technological and legal) have to be considered and these are external to the organisation. Campbell, McAllister and Eley (2012) are of the view that both intrinsic and extrinsic factors of motivation can go a long way in motivating and retaining employees in organisations.

Peresuh and Nhundu (1999) feel that for individual employees to achieve the desired outcomes they should have the ability and an enabling environment, which perhaps could be lacking in rural schools. Organisations should create environments which allow for innovativeness and team building. Such organisations can lead to great satisfaction of employees. Freedom to exercise self-control is also critical for organisations to be successful. Motivation is not manipulation or management through fear or coercion but a conscious effort in which individuals choose to behave in certain ways towards achieving both personal and organisational goals (Wright and McMahan, 2011). Cole (2009) avers that motivation is linked to satisfaction, commitment and loyalty to the organisation. As mentioned earlier on, motivation and retention are key to this study. Theories on motivation and retention are going to be discussed in this section. Most theories of motivation imply aspects of retention as well and therefore double as models of motivation and retention. There are many theories of motivation and most of these theories were developed in the Western World and these have been transferred to Africa and other continents without adjusting them to local jurisdictions. This could be one of the reasons for their failure.

\subsection{Theories of Motivation}

The basic theory of motivation to be reviewed first is that of Urcdziková and Kiss (2009) which is referred to only as the simple model of motivation as illustrated in Figure 1.1. According to this theory, people always have needs and these stimulate certain behaviours towards achieving satisfaction. These needs could be both at an individual and organisational levels. Individual and organisational needs have to be satisfied at the same time in order to realise improved productivity in organisations. As its name implies, this theory is very simple and offers the very basic skeleton of every model of motivation including the one below. Because of its simplicity, it does not elaborate on what should be designated as a need, behaviour and satisfaction. Thus, it is very difficult for any given group of researchers to come up with the same categories of data to measure and use as a theoretical framework. 


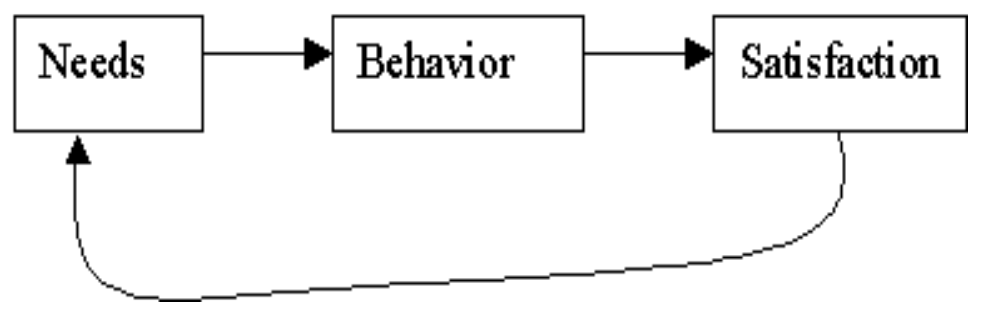

Figure 1: The Simple Model of Motivation

Source: Urdziková and Kiss (2009).

\subsubsection{Maslow's Hierarchy of Needs Theory}

Maslow in 1950, proposed the Hierarchy of Needs Theory (McLeod, 2007). Maslow arranged employees' needs in order of importance and indicated that these are satisfied following the prescribed order. According to Maslow, these needs start from the bottom (physiological to selfactualisation needs) and that these are fulfilled systematically as shown by Figure 1.2. However, this theory has its weaknesses. Even though shelter is regarded a basic need according to Maslow, what was pertaining on the ground was that accommodation that was available in most rural schools was either inadequate or dilapidated. For motivation strategies to be effective, management should consider employees' motivation at an individual level and the context in which they are operating (Baron and Greenberg 2003: Werner (2007).

Maslow's theory did not address motivational needs at an individual level. It should be noted that employees are not the same and that they react differently to different motivational strategies. In the real work environment, Maslow's needs cannot be satisfied in an orderly manner as portrayed since some of them can be fulfilled simultaneously. This theory was not comprehensive in its approach as other variables that make employees stay in their jobs were not considered. The external environment which affects directly or indirectly on both employees and organisations were not considered. For instance, the global economic meltdown is external to the organisation but can end up affecting organisations, employees and the society in general. This theory fails to address the basic needs of an employee from a Zimbabwean perspective. Employees' needs are not uniform and cannot therefore be applied holistically. Maslow's Hierarchy of Needs Theory is viewed from the aspects discussed below.

\section{$>$ Physiological $/$ basic needs}

With reference to this study, when teachers graduate from colleges and universities their desire will be to get employment in order to meet their basic needs such as food, shelter, sex and others. This is when people starting building their future on the basis of their current employment. At this stage of their lives, they are not worried about where they are deployed and how much they get, their desire is to get a job and get going. As time passes employees aspire to achieve more and grow in their careers.

\section{Safety}

As they get more experience, they start acquiring property in the form of furniture, electrical gadgets such as smart phones, television sets, computers and many others. They also want to be protected from physical and emotional harm in their endeavours to serve communities around them. They start aiming higher and looking for better opportunities beyond the rural communities that are obviously urban communities. As they get more and more experience, they would want to improve themselves in all spheres of life. 


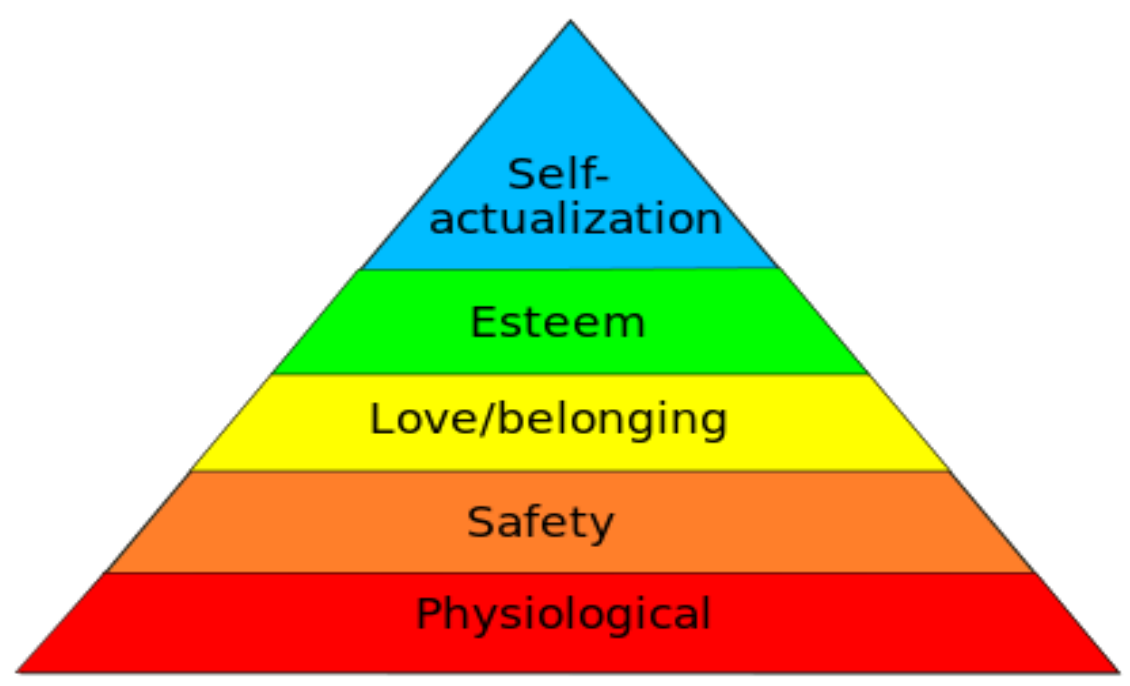

Figure 2: Maslow's Hierarchy of Needs Theory

Source: Cole (2009)

\section{Social needs}

When the lower needs are met, employees would want to get friends, fill affectionate about others. Since most teachers are perceived to be enemies of the ruling party, the Zimbabwe African National Union-Patriotic Front (ZANU PF), they do not have freedom of association even though freedom of movement and expression is enshrined in our Constitution. It is perceived that parents who send their children to these schools are the same people who perpetrate violence on teachers.

\section{Esteem needs}

At the fourth level in Maslow's hierarchy is the need for appreciation and respect. Teachers who work in rural areas need to be respected as transformers of society. Since most of the needs would have been fulfilled, the esteem needs begin to play a more prominent role in motivating behavior. When teachers produce good results, their efforts need recognition. Prestige at this level plays a critical role. At this level, monetary rewards are not as important as recognition. It seems teachers' efforts have not be recognised in any way. By the end of the day, they feel that they are not important and that their work is not important as well. They end up wanting to move to urban areas where there are better opportunities in every sphere of their lives. It seems as if it is at this point, that most teachers seek transfers to better schools.

\section{$>$ Self-actualization}

Even though this level is difficulty to achieve, it is the desire of everyone in life to reach their fullest potential in their careers and life beyond the careers. For teachers, this level has been difficulty to achieve because the environment they are operating in, rural schools does not permit that. Promotions are difficulty to come by. To this end, teachers will continue to make efforts in trying to fulfill this need by placing themselves strategically. In urban areas, there are opportunities of consulting, getting better opportunities and advancing themselves professionally. So this why it is important to understand how motivation functions at various levels. It also critical to come up with what teachers perceive to be motivation. It seems there is lack of engagement and consultations when it comes to the conditions of service for teachers. What is interesting is that what is called motivation, could not be viewed the same by teaching 
practitioners. What is also clear from the above discussion is that motivation is a function of management. It is against this background that the researcher seeks to develop a model that can assist management in motivating and retaining experienced and qualified employees.

\section{Objective}

The objectives of this study were to:

Evaluate the application and implications of Maslow's Hierarchy of Needs Theory from rural teachers' perspective; and

Synthesise the analysis into a model of motivation of human capital

\section{Methodology}

This section gives an account of the methodologies, procedures and analytical tools used in carrying out the study. The study used the qualitative research design and the case study approach. The factors considered for selecting the case were:

1. The case provided fresh insight to a previously generalised problem through an in-depth analysis.

2. The case was thus, considered to have the ability to provide a basis for pursuing remedial action on the problem of motivation;

3. The case challenged the existing models of motivation and offered a counter-theory to prevailing theoretical frameworks that are largely euro-centric and assumed that human needs considered as basic human rights in the West were the same as basic human needs everywhere; and

4. Analysis of data from the case was deemed appropriate and sufficient to generate an indigenous theory and thus offered a fresh direction for future research where the theory may be tested to further ground it in other alternative contexts.

Mazowe District has three mission-boarding secondary schools and one Government primary boarding school. Some teachers from the four boarding schools formed part of the purposive sample of this study. The other six-day schools were also purposively selected and some teachers from these schools participated in the study. The respondents were chosen considering the accessibility of the respondents, their willingness to participate in the study and their experiences and knowledge as teaching practitioners in Mazowe District. Patton (2002) submits that the selection procedures are dependent on the variables being considered by the researcher.

\subsection{Considerations for choosing Mazowe district as the study area}

The study focused on rural schools in Zimbabwe. Zimbabwe has a total of 60 districts situated in ten the provinces of the country. Eight of the provinces have districts that are largely situated in rural areas. The rural areas have the following characteristics:

$>$ Low household income often inadequate to cover school fees;

> Poor infrastructure and facilities such as road networks, communication, service centres and many others; and

$>$ Poor pass rates 
Ordinarily, the choice of the study site is premised on the need to select a district that is representative and typical of any rural district in Zimbabwe. In this study, however, the choice of the study area was informed by the results of the preliminary desk study on the state of rural education in Zimbabwe. The desk study revealed that Mashonaland Central province had the lowest number of trained primary and secondary school teachers at $24.1 \%$ and $57.4 \%$ respectively. The Zimbabwe Vulnerability Assessment Committee Report (2017) and the Medium Term Plan Education in Zimbabwe (Coltart, 2013) were used to provide this basic information. Out of the eight districts in Mashonaland Central Province, Mazowe district was purposively selected considering its proximity to urban centres notably Harare, Chinhoyi and Bindura. Findings from such a district would therefore imply that other rural districts cannot have better conditions. The researcher was cognisant of the fact that although districts may share common characteristics, every district presents a unique set of issues.

A case study is a qualitative methodology which studies a phenomenon in its natural setting (Sunders, Lewis and Thornhill, 2012). A much more detailed and preferred definition for this study comes from Mills, Durepos and Wiebe (2010). This school of thought argues that the term case study refers to a methodology for examining a problem, associated with a person, place, event, phenomenon, or other type of subject of analysis in order to extrapolate key themes and results that help predict future trends, illuminate previously hidden issues that can be applied to practice, and/or provide a means for understanding an important research problem with greater clarity. Thus, this study sough to evaluate applications and implications of Maslow's Hierarchy of needs in motivating and retaining rural teachers.

\subsection{Population}

Mazowe District has an establishment of 2090 teachers (including Headmasters) for both primary and secondary schools and 10 District Officials. The current staff strength of 1520, 10 District Officials, 10 schools development chairpersons, 10 teachers who had left teaching and the Provincial Education Director formed the population of the study. The population for this study was therefore 1551 . While numbers are mentioned here, it does not mean the numbers are significant as far as drawing meaning from the data is concerned. Their significance lies in the fact that the population was large enough for data collection until saturation point.

\subsection{Sample size}

The criteria for coming up with the sample were:

> Individuals with five years or more as teaching practitioners;

$>$ Type of school-boarding/day;

Location of a school in terms of accessibility; and

$>$ Willingness of the respondents to participate

\subsection{Sampling techniques}

This study employed a number of non-probability sampling methods based on an appreciation of the nature of the population under study namely the purposive, expert and snowballing nonprobability sampling methods. The goal of the qualitative study was to provide an in-depth understanding as to why teachers in Mazowe district shun rural schools from Maslow's point of view. To accomplish this goal, the qualitative research focused on criterion-based sampling techniques to reach the target group. Purposive sampling, expert sampling and snowballing sampling were used in the study. The reasons for choosing these sampling techniques are discussed below. 


\subsubsection{Purposive Sampling or Judgemental Sampling}

Purposive non-probability sampling is a sampling method that produces a purposive nonprobability sample. Sources are not uniform regarding the nomenclature. This study follows Kumar (2011) and Cooper and Greenaway (2015) who use the term purposive sampling to refer to this method and a purposive sample to refer to the sample that comes out of this method. The researcher only approached people who met certain criteria based on the researcher's consideration of whether the data provided would meet the objectives of the study. In this case, experienced teachers, heads of schools and senior district officials were purposefully chosen to participate in the study.

\subsubsection{Expert sampling}

Expert sampling is a non-probability sampling method and it occurs when elements selected for the sample are chosen by the judgment of the researcher in this case expertise and experience as education practitioners in rural schools. This study follows Kumar (2011) and Cooper and Greenaway (2015) who use the term expert sampling to refer to the sample that comes out of this method. The researcher approached people who met the criteria based on the researcher's consideration of whether the data provided would meet the objectives of the study. The Provincial Education Director, the District Schools Inspector (DSI), the District Inspector (DI) the Human Resources Officer (HRO), ten teachers who had left teaching and ten heads of schools formed the experts of this study. The Human Resources Officer interprets and advises the DEO on issues relating to employment regulations and conditions of service for teachers. Therefore, the expert sample for this study was thirty three (33) including twenty heads from the twenty schools visited.

\subsubsection{Snowball Sampling}

The snowball non-probability sampling method is used to collect data from a group or organisation that the researcher has very little or no knowledge about (Kumar, 2011). The method arrives at a sample by utilising networks. In this study, the researcher began with one person who met the researcher's criteria. Information was collected from the respondents and then the researcher used the respondents to identify others from whom information was collected. The latter became part of the sample and the researcher requested these respondents to identify others from where data were collected and these too became part of the sample and the process recurred until the researcher had the desired data. The researcher was referred by other respondents to senior officials or individuals who had valuable information. In terms of infrastructure, the researcher was also referred from one school to another. This helped the researcher to make some comparisons and draw conclusions from what he had gathered from the respondents and had observed. Some pieces of data were not easily accessible especially those that officers and, or, teachers either felt they were protected by the official secrecy act or divulging such data would get them into trouble for political reasons or otherwise. The snowball sampling technique became useful.

\subsection{Data collection methods}

Data collection offers the opportunity for assessing research design within each tradition of inquiry. The researcher needed to have determinant data collection instruments (Creswell, 2007; Locke, Silverman, and Spirduso, 2010; Marshall and Rossman, 1999). The instruments used for data collection in the study were interviews, observations and review of documents at the district offices. The researcher pilot-tested the data collection instruments on a different group before carrying out the full-fledged research. The idea was to improve on the instruments. 


\subsubsection{In-depth interviews with key informants}

Even though the interviews were time-consuming, they became the researcher's main datagathering method. The researcher used unstructured interviews with key informants and semi-structured interviews were done with teachers. In-depth face-to-face interviews were done with the PED, DSI, DS and the Human Resources officer to get an in-depth understanding of why teachers shun rural schools. Interviews were done with selected teachers, SDC chairpersons and heads of schools. This helped the researcher to get actual reasons as to why teachers wished to transfer to urban and boarding schools. As way of validating responses from other categories, the researcher managed to track down ten teachers who had left the service and interviewed them as well. This provided balanced views on the issues affecting teachers in rural areas.

\subsubsection{Focus group discussions}

In order to get an in-depth understanding and appreciation of what motivate rural teachers, ten (10) focus groups with ten members each were formed. All the four boarding schools became part of the four focus groups and the remaining six focus groups were formed out of the rural day schools. An interview guide was used and the researcher directed the discussions. The purpose of the focus group discussions was twofold: first, the focus discussion group sessions were meant to generate as much data and knowledge as possible that would allow the data generation to reach saturation point. It was also a way of authenticating the submissions by the respondents; second, the sessions were meant to assist the study to arrive at trustworthiness through peer reviewing and debriefing, member checking and thick descriptions.

\subsubsection{Direct observations}

In qualitative research, observation as a method of collecting research data involves observing behaviour and systematically recording the results of those observations. Besides observing the behaviour of teachers, the researcher also observed the state of infrastructure and facilities in the schools visited. The observation guide which was developed by the researcher informed the observations. A checklist was used to assess the suitability of infrastructure and other facilities in the visited schools.

The researcher took detailed descriptive notes of the observations. The observations offered the researcher with a flavour of what was happening in the schools visited. This also gave an insight into the bigger picture of what could be happening in other rural schools around the country. Classrooms, roads, laboratories, teachers' accommodation were observed. This was done in order to link the behaviours and attitudes to the motivational levels of the teachers and how this prompted rural-urban migration. The observations provided useful data to the researcher and opened new avenues for future researches.

\subsubsection{Document analysis}

The researcher further analysed documents from the District offices, as these were a rich source of valuable secondary data. Documentary analysis complemented data gathered through interviews and observations. The researcher reviewed the following three documents: Public Service Act Chapter (16:04); Public Service Regulations Number 1 of 2000 as amended in 2001; and the Principal Procedures. The reasons for choosing these key documents are that, the SI 1 of 200 is the code of conduct for all civil servants, teachers included. The Principal Procedures cover appointments, promotions and regradings of teachers. Further to the review of the above documents, various registers were also analysed and they provided vital information on the 
movement of teachers within and outside the district. The idea was to assess the effectiveness of the three primary documents in the efficient management of teachers in rural schools.

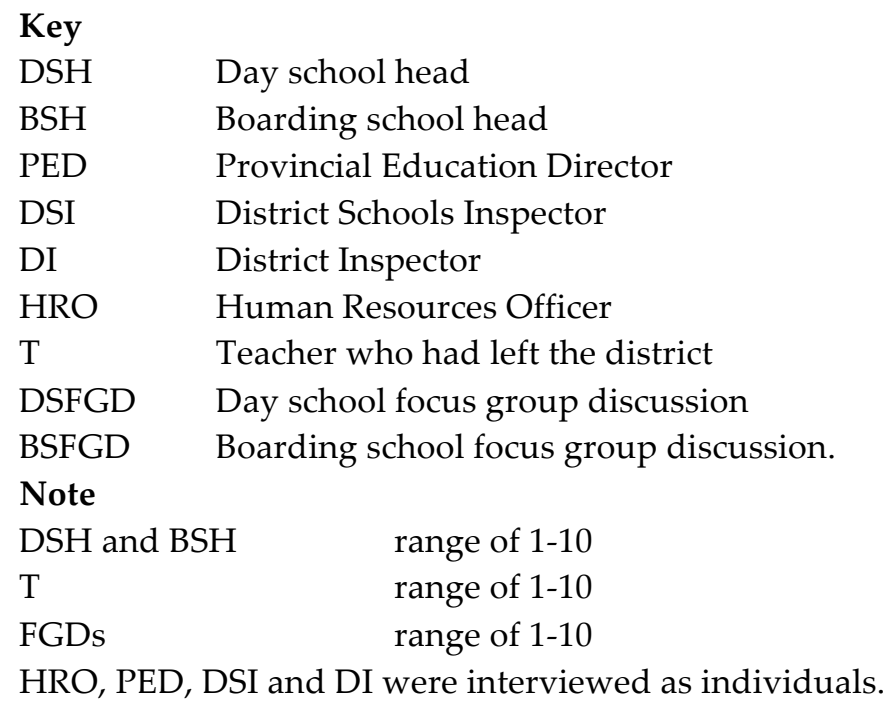

\section{Findings}

The study found that the employer was failing to meet all the needs as portrayed by Maslow's Hierarchy of Needs Theory. The findings are presented in the sections that follow. The responses from all the categories of the respondents are nested in Figure 3.

\subsection{Violation of physiological needs}

The nesting of the Maslow's Hierarchy of Needs Theory shows that the basic needs of the employees were not being adequately addressed. The fact that salaries were too low to meet the respondents' basic needs was a 'violation' of the respondents' basic rights. There was consensus that rural schools had failed to provide basic services such as clean water and health facilities. Poor working conditions in terms of infrastructure, amenities, teaching and learning resources were cited. Accommodation and salaries were cited as the main reasons why teachers were failing to meet their basic needs. Even though most schools provided accommodation, it was dilapidated and inadequate. T5 had this to say. "I decided to pack my bags and leave. Currently, I am teaching at a private college and my salary is two times more than what I was getting when I was in Government. I now lead a better life than before." Figure 3 show responses pertaining to the levesl of salaries.

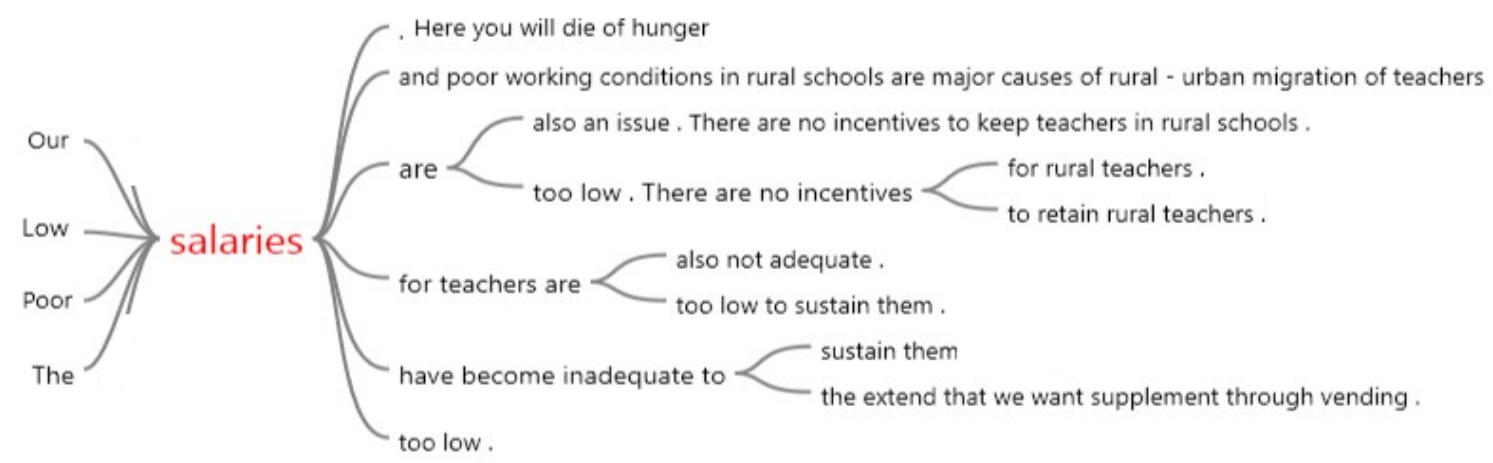

Figure 3: Responses on the levels of salaries

Source: Field data 
The responses were indicating that accommodation was a problem in most schools in the district.

"Accommodation was a problem at my former school, most of us were sharing thereby making privacy seem as a luxury and not the right that it should be. Our properties could not be accommodated and to add insult to injury, some of us had big families. With respect to their condition and ambience, these houses were not habitable at all." (T 3).

As T8 observes: "I had one small room to share with my wife and my two siblings thereby negating on privacy". The situation is worse in satellite schools where tobacco barns were housing teachers despite not providing proper ventilation and not being fit for that purpose. The houses available were ancient and parents could afford to construct new houses for teachers due to their poor economic status. DSH1 bemoaned his housing plight: "Even I as Head, share with two teachers. Is there any element of respect that I can expect from the society and my staff? At one of my satellite schools, farm shades are used as makeshift teachers' houses." Figure 4 populates the responses on the state of accommodation in the district.

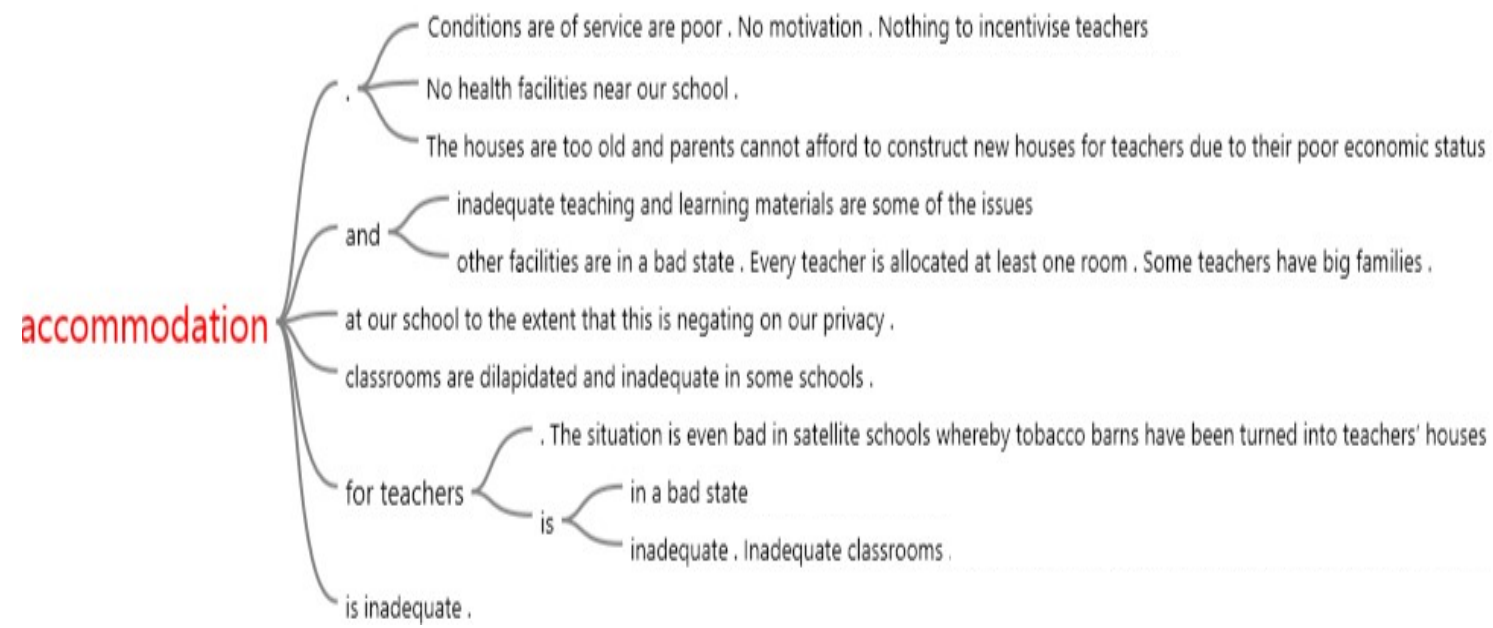

Figure 4: Responses on the state of accommodation

Source: Field data 


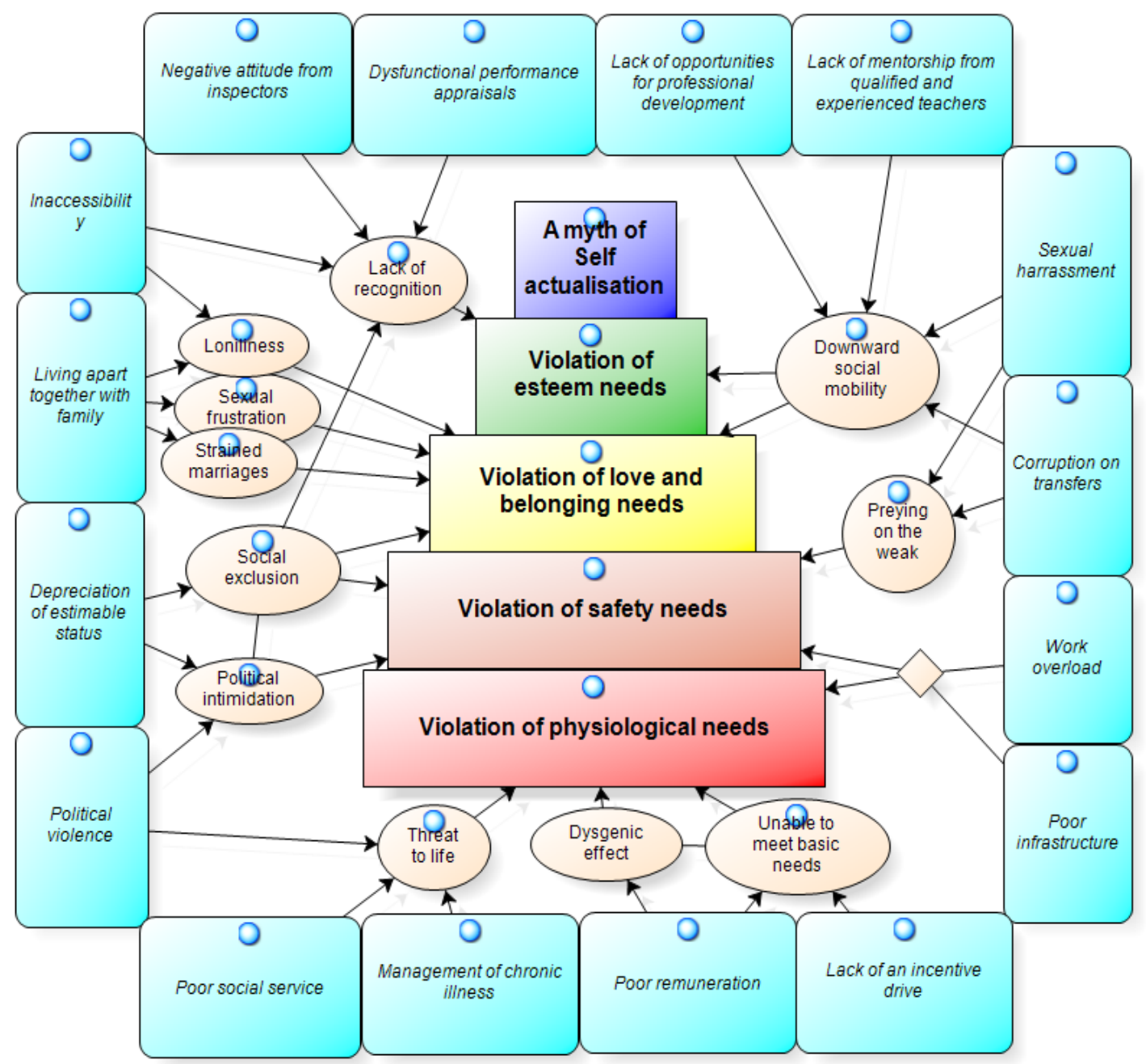

Figure 5: Responses on Maslow's Hierarchy Needs of Theory

Source: Field data

\subsection{Violation of Safety needs}

There was consensus that there was serious violation of safety needs of the respondents by political parties. The PED had this to say, "Some teachers in Mazowe District are being protected by the courts. Court orders have been issued against the perpetrators of political violence. Reports which have been coming to my office are that, ZANU (PF) supporters are the main perpetrators of political violence." All the respondents concurred that security was a cause for major concern. 


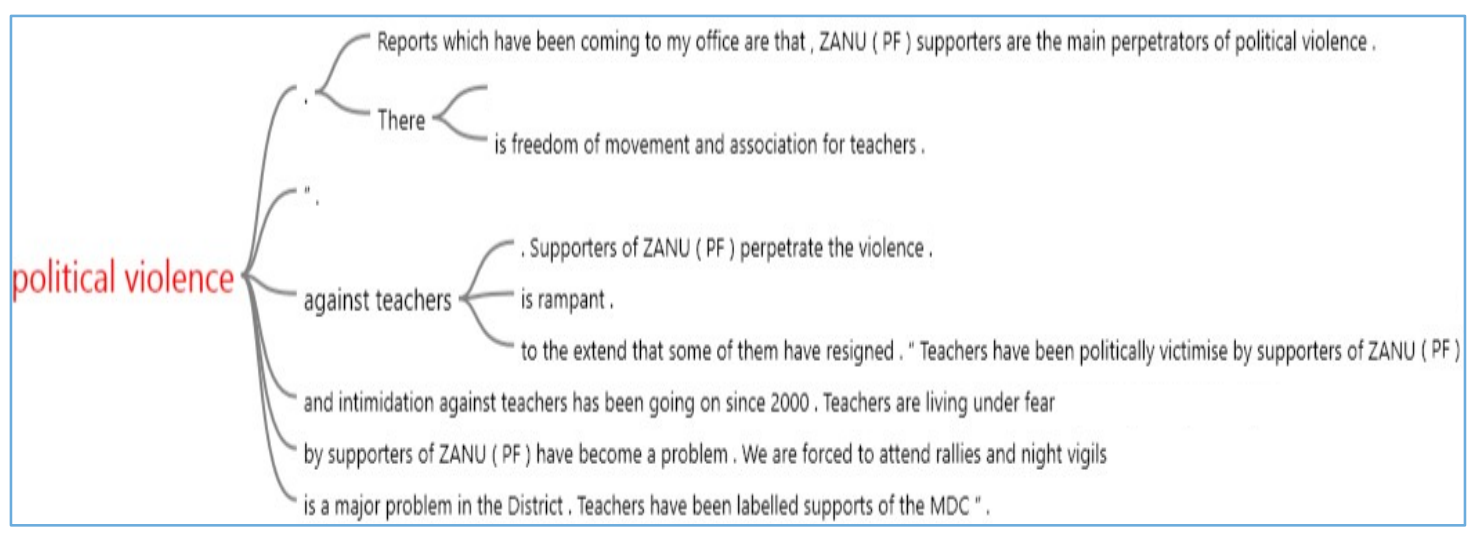

Figure 6: Responses on the nature of violence

Source: Field data

\subsubsection{Boredom}

The study established that civic facilities were lacking yet critical for development of social life. There is lack of entertainment in rural schools leading to boredom which is counter-productive.

We need to have light moments after the day's hard work. The only entertainment is in the form of beer drinking, going to church (African Independent Churches of the apostolic type) listening to radio or watching television. However, the Zimbabwe Broadcasting Cooperation transmission is very poor. This forces some few teachers who can afford to buy satellite decoders and dishes but still subscriptions are a big challenge for two reasons, namely affordability in terms of monthly subscriptions and travel to and from the surrounding towns were DSTV agents are found. [T8].

For some of us who take alcohol, spend our social lifetime patronizing the beer halls in our area and where these are not available some teachers are forced into taking illegal staff like kachasu (some home brewed clear beer)" [T1]. Most of the respondents concurred that there was limited entertainment in rural areas.

\subsubsection{Preying on the weak}

The respondents were victims of circumstances due to their desperate situations. Greedy officials were found to be taking advantage of the desperate situation of teachers.

Since teachers will be desperate to transfer, they end-up being victims of circumstances. Senior officers have been preying on the weak to the extent that some female teachers are full of regrets and embarrassments. Reports have been made to higher offices and nothing has been done. Senior officers are taking advantage of the situation to sexually abuse female employees and asking for bribes from male teachers [BSFGD7]." Most of the respondents agreed that they were being taken advantage of.

\subsection{Violation of love, belonging needs, and social exclusion}

The fact that there is no freedom of movement and association in the district was found to be a violation of love and belonging needs. Teachers were called names such as traitors, saboteurs, sellouts for supporting opposition politics and they were also blamed for being critics of some of the government policies. They became social and political outcasts in the district and such teachers were left out in developmental and social programmes and projects. They felt that they 
that they were no longer part of the communities they were serving. The only places they could find solace were churches and beerhalls but still negative labeling was there.

\subsubsection{Sexual frustration and strained marriages}

The responses given indicate that there was loneliness and sexual frustration among the respondents who were not living with their families due to different workstations, professions or inadequate accommodation at their workstations. There was also consensus that sexual frustration was leading to prostitution that was likely to lead to high prevalence of HIV and AIDS in rural schools. This led to strained marriages and relationships and high rates of separations and divorces.

\subsubsection{Violation of esteem needs/ Lack of recognition}

The respondents reveled that there was serious violation of esteem needs. There was lack of recognition and appreciation for the work done by teachers. DSFGD1 had this to say, "There are no prospects for promotion since there are limited vacancies in our schools." DSFGD1 added, "We feel that our work is not appreciated by our superiors."

\subsubsection{Retrogressive movement and downward social mobility}

The situation on the ground showed that there were acts of retrogressive movement on the part of the respondents. There was backward movement because the status of the respondents was said to be depreciated to the lowest levels since the year 2000. The respondents had the desire to move up the social ladder, which is theoretically possible by working hard, applying oneself, and making connections with others. In this case, it was found that rural teachers were moving down the social ladder social due to political violence and limited freedom of movement and association in the communities they worked.

\subsection{A myth of self-actualisation}

The findings of the study pointed to the fact that rural schools were failing to meet the basic needs of teachers let alone the esteem needs. The question which remains unanswered is 'Can it then be possible for teachers in rural schools to self-actualise, when the lower and middle level needs are not met? This is why the respondents indicated that it was myth and will remain a dream.

\section{Conclusion and Discussion}

This section concludes and discuss the findings in relation to the findings and literature.

\subsection{Violation of physiological needs}

This study established that there were serious violations of basic needs for teachers in Mazowe district, which also is a violation of Article 25 of the Universal Declaration on Human Rights . The Article states that everyone is entitled to the right to adequate food, water housing, clothing and medical care. The right to medical care implies the right to live a healthy life, or at least healthy to the best of ability of a particular individual. All these were found to be lacking and then it becomes difficult to talk about a reasonable working and living environment. From the finding of this study, it is very clear that rural teachers were leaving in very poor conditions. What is also not clear about Maslow is the type and nature of accommodation. He should have at least talked about decent accommodation, proposing standards not just shelter. Teachers are an elite group in our society and they should be treated as such. The findings of this study are contrary to Hosseini (2013) who avers that motivation of employees is influenced by working conditions (Hosseini, 2013). 
This right to medical care as a universal right of all human beings can be interpreted to mean many things. For the purposes of the comparison to the Maslow's Hierarchy of Needs Theory, it could be interpreted as a physiological need. The fact that teachers were living in dusty conditions means that this could also affect their health that means that their lives will be in danger since some of them were said to have allergies and some were asthmatic. Accordingly, the employer was found to be violating the industrial and labour laws as well as failing to observe the article on The Universal Declaration of Human Rights. This is contrary to Maslow's Hierarchy of Needs Theory.

\subsection{Undignified activities}

Respondents who had left the district indicated that most teachers were involved in undignified activities in order to make ends meet. Undignified actives are actions which are embarrassing to the one who is performing them. In this study, most teachers were found to be engaging in vending, minerals panning and cross border trading which was not befitting to their once esteemed profession. From a human resources point of view, it is extremely undignified and unacceptable for a professional to become a vendor. In Zimbabwe, vending used to be and is still trade for the poor in our communities. This is a sign of extreme violation of employees' rights, and violating Maslow's esteem and self-actualisation needs. Such situations are embarrassing to the employer, the employee and the family of the employee. This is the current position in the Zimbabwean rural schools. The fact that employees engage in undignified activities to raise money means that the employer has failed to meet basic needs.

\subsection{Violation of safety needs}

Political intimidation and physical assault of teachers was a major security concern and violation of Maslow's Hierarchy of Needs, level 2 (Safety needs). Issues covered at this level include protection form physical harm, order, law security and freedom from fear. It is very difficult for anyone to engage and work effectively and successfully when they are constantly stuck in fights and being singled out for abuse. Common sense tells us that it is not possible. When a person is victimised that person is clearly not safe in that particular environment. When people are victimised, they often become vigilant and their time and energy, which should and would, under normal circumstances, be spent focused on job performance and other priorities in life, is instead spent focusing on ways to be and stay safe. There is no stability on the part of victims and obviously, schoolchildren bear the consequences. From the findings of this study, it was clear that teachers were under siege from ZANU (PF) supporters.

\subsection{Violation of love, belonging needs and social exclusion}

Teachers were found to be deprived of love and belonging needs and there was also serious social exclusion. Teachers were outcasts and their socialisation was limited to family members only and close friends. Their social exclusion emanated from the perception that they were agents of political change. It was also felt that they were decoding information with political connotations in the communities they were working. Anyone associated with teachers was also socially excluded.

Politicians and senior officials were causing havoc on teachers. Staffing officers were taking advantage of the desperate teachers to solicit for bribes and sexual favours. On the hand, politicians know that there is no observation of the rule of law and they take it upon themselves to abuse teachers. The situation was found to be bad and not helping the situation at all. They took advantage of the teachers' weak status. Teachers who were not living with their families were being sexually starved and could end up engaging in prostitution leading to strained marriages and relationships. The theories of motivation, management and retention 
discussed in the literature section do not adequately address the modern day human capital issues in organisations as evidenced by the issues raised by the respondents in this study. In order to address the challenges highlighted by the respondents, a localised model of motivation was proposed and is presented in the section that follows.

\section{Model of motivation of human capital}

Accordingly, using the data that were collected through in-depth interviews, observations and the review of documents, this chapter focuses on the development of a suitable model for use in addressing the concerns raised by teachers in Mazowe district, the country in general and beyond. The development of the model is consistent with objective number 2 which intended to synthesise the findings of the study into a model of motivation of human capital with the view of motivating employees in a local environment. The model which will henceforth be referred to as the 'Motivation theory of Human Capital' (see Figure 4) was developed taking into cognisance the weaknesses identified in Maslow's Hierarchy of Needs Theory in addressing issues raised by employees at the workplace and issues raised by the respondents in this study. As a way forward, the model proposes a review of all current policies by looking at the identified critical motivational factors and the suggested strategies. The components of the model are closely linked to the recommendations.

The model seeks to addresses the following key areas:

$>$ Critical motivational issues;

$>$ Mitigatory strategies;

$>$ Review of current policies; and

$>$ Decentralised decision making

It is believed from the research findings that, a holistic application of the model could go a long way in addressing most of the issues raised by the respondents. The employer needs to critically analyse what is motivation from the respondents' perspectives considering their local environments. Further more, coming up with appropriate mitigatory strategies will go a long way in motivating and retaining rural teachers. Further to that, the review of current policies by decentralizing decision-making will improve motivation of teachers in rural schools and beyond. 


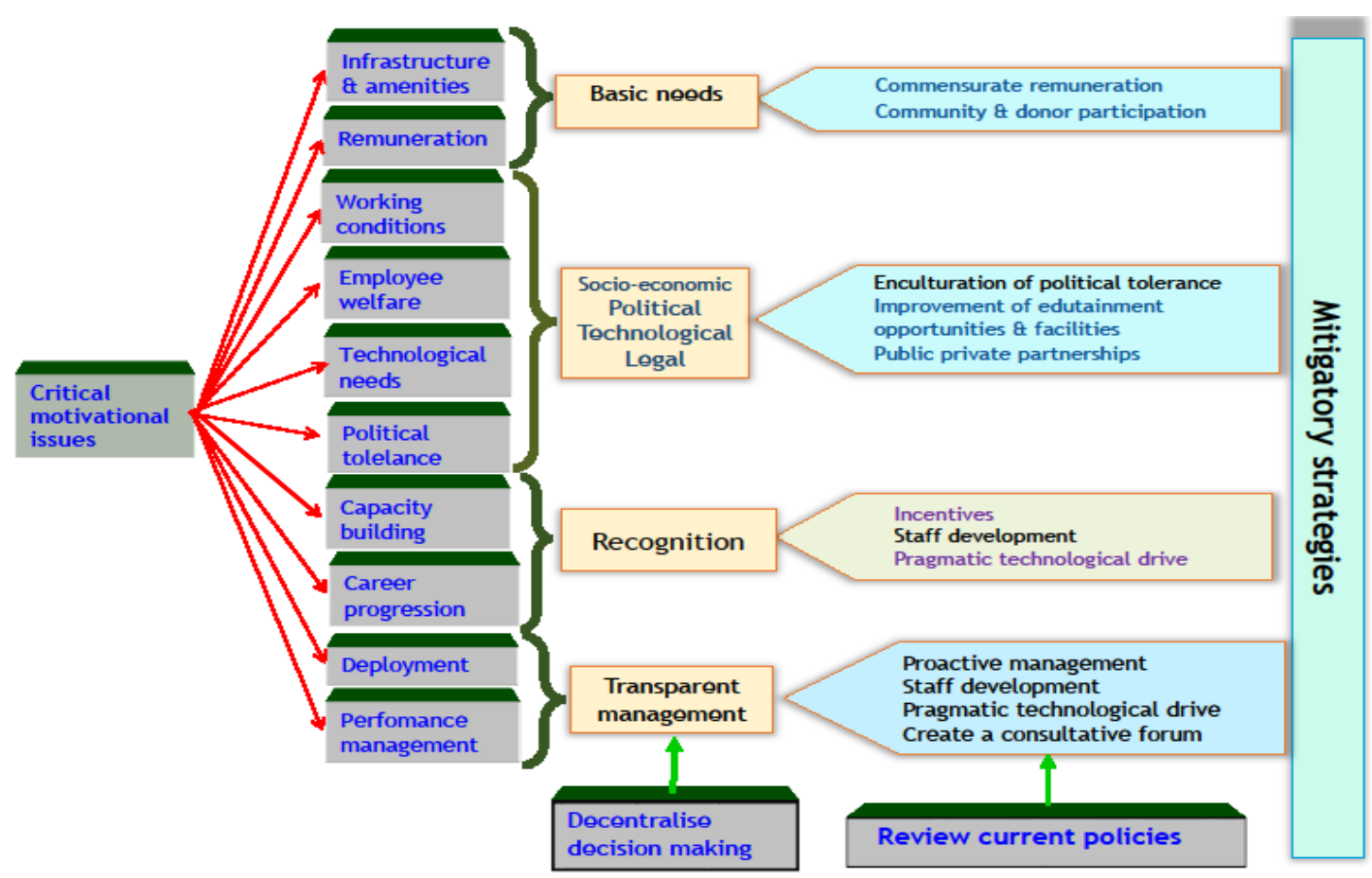

Figure 7: Model of Motivation of Human Capital (Researcher's model)

\section{Recommendations}

At this stage, coming up with relevant action or interactional strategies directed at managing the phenomenon, is the major goal of this study. It is particularly because of this goal that the researcher developed a model of motivation of human capital grounded in the findings of the study. This study aimed at coming up with relevant action or interactional strategies directed at motivating and retaining teachers in rural schools.

The government should provide decent accommodation for all the teachers that match those of either urban or boarding schools or even better. It is critical to build standard classrooms and related infrastructure, especially proper administrative blocks that match the classrooms and related infrastructure in either urban or boarding schools or even better. It is critical to reach out at the communities from where learners come using both traditional leaders and political structures so as to improve the teachers' relationships with parents in a bid to make parents appreciate and value teachers as vehicles of socio-economic development in their communities and the nation at large.

Since health is a basic need, there is need to improve health facilities and make them relatively accessible and affordable. There is need for liaison among the responsible Ministries of Transport and Infrastructure Development, Health and Child Care, the District Development Fund and local authorities to upgrade the roads and make health facilities available and accessible. The Government also should introduce community halls and sporting facilities in the rural areas and to encourage the Zimbabwe Broadcasting Cooperation to improve coverage in rural areas so as to improve the teachers' entertainment options. That way, it may also restrain teachers from abusing alcohol and this may improve teacher attendance and attention in class.

It is critical for SDCs to enhance involvement including strengthening home-school ties, equipping schools with the necessary resources to enable them to involve parents in more 
meaningful ways, exploring other avenues of communicating with parents and sensitising them on the need to be actively involved in the education of their children.It is also plausible that development partners such as the United Nations International Children's Emergency Fund (UNICEF) donated some textbooks in most schools around the country. The development partners should go an extra mile by improving infrastructure in rural schools to the same levels with urban areas. They should continue to assist in areas where the government is having challenges such as in the improvement of infrastructure, the provision clean water, provision of information and communication technology and other basic services in the areas of health.

The PSC should pay a reasonable salary that commensurate with qualifications and experience. The introduction of a hardship allowance for rural teachers may go a long way in mitigating the rural-urban migration of human capital in Zimbabwean rural schools. The introduction of money and non-monetary incentives such as residential stands/houses may go a long in addressing the plight of teachers on accommodation. The employer should also allow after work entrepreneurship so that teachers can supplement their basic salaries which have become inadequate. The recruitment and selection processes need to be decentralised so as to wade off corruption and issues of sexual harassment. The PSC should move away from the bureaucratic tendencies in order to make speed decision making.

Unfreezing of performance related salary increments and study leave so that teachers may improve their skills through the conventional system and studying through ODL may become optional for those in favourable conditions is critical. The PSC should allow teachers to proceed on manpower development leave on full salary in line with what is prevailing in the security sector. The employer should also offer financial assistance to those who wish to develop themselves professionally. It is critical to introduce workers' committees at school level so that issues affecting teachers can be addressed at the shop floor level and this leads to timeous decision-making. It is desirable to involve teachers in critical decisions and other engagements.

There is need to improve the Ministry of Primary and Secondary Education internal systems especially to wade off corruption, and adopt affirmative action in the deployment processes, for instance, in the deployment of university graduates and couples. Reviewing the Public Service Act (16:04) and other related statutes will allow teachers' representative bodies at grassroots level that feed into the national representative bodies so that collective bargaining starts at a local level. Creating a legal framework and conditions of service for rural teachers and other civil servants in rural areas may go a long way in addressing the problem of rural-urban migration of human capital in Zimbabwean rural schools.

Exercising political tolerance and respecting the teachers' basic human rights, especially discouraging political violence against the teachers will ensure their safety. Political parties need to be reminded that teachers like any other citizens have a right to choose political parties to support. The harassment of teachers need to stop if the quality of education is to improve in rural areas.

\section{Implications for practice}

Many researchers and scholars have come up with many theories of motivation which have failed to stand the trial of time. Retention strategies proposed in Zimbabwe, and elsewhere have also failed to address the problem of motivation. Teachers in rural schools operate in unique environments which are highly challenging. Rural schools continue to produce poor results due to a number of challenges some of them mentioned in this study. The Motivation Theory of Human Capital in this study, if applied holistically, could go a long way in mitigating the ruralurban migration of human capital in Zimbabwe and other countries facing similar challenges. There is need to recognise and appreciate that motivation has become complicated and personal 
to the extent that global motivational strategies may not be applicable in modern day organisations. Schools are organisations which are critical for developing and nurturing talent that is critical for the future development of our communities and the nation at large. Managers need to identify needs which are peculiar to groups of employees so that targeted strategies can be applied. There is also need to appreciate that rural teachers operate from different environments from their urban counterparts. This will assist managers in coming up with appropriate strategies in addressing issues raised by a particular group, in this case rural teachers.

\section{Conclusions}

A myriad of management practices, political, economic, social, technological and legal factors were identified as the reasons why teachers were not motivated. The researcher understood what constitutes motivation from the rural teachers' point of view. Teachers were not comfortable to work in rural schools due to the poor working and living conditions, lack of teaching and learning materials and lack of incentives. In this case, the quality of education was compromised due to these and other challenges. Accommodation for teachers in rural schools was found to be inadequate and dilapidated and sharing was negating teachers' privacy. It is therefore, critical for the employer to provide decent and adequate accommodation for rural teachers. This could go a long way in addressing accommodation issues raised by teachers. It was also sad to note that basic services and infrastructure were lacking and it was serious in satellite schools. The unavailability of health facilities and clean water were a challenge since this exposed teachers and school children to diseases. The study therefore concluded that the employer was failing to meet the basic needs of rural teachers. Their physiological, safety, social self-actualisation and esteems needs were being seriously violated. Deployment was not fair since sexual harassment and corruption were reported to be rampant in the district. The performance management system was found to be ineffective and not adhering to its tenets. The issues of inadequate salaries and lack of incentives were also raised.

\section{References}

Baron, A.R. \& Greenberg, J. (2003), Behaviour in Organisations: Understanding and Managing the Human Side of Work. Englewood Cliffs: Prentice-Hall.

Belle, L. (2007), The Role of Secondary School Principals in Motivating Teachers on the Flacq District of Mauritius: A dissertation submitted in partial fulfilment of the requirements of the University of South Africa for the degree of Master of Education. Pretoria: University of South Africa.

Blunt, P. \& Johns, M.L. (1992), Managing Organisations in Africa. New York: Walter de Gruyter.

Campbell, McAllister \& Eley (2012), The influence of motivation in recruitment and retention of rural and remote allied health professionals.

Chin, K. S. \& Sofian, S. (2011), 'The Impact of Human Capital and Total Quality Management on Corporate Performance'. Interdisciplinary Journal of Contemporary Research in Business. vol. 3, issue no. 3 .

Chindanya, A. (2002), Motivating Professional Staff as a Managerial Task at a Higher Education Institution. A dissertation submitted in partial fulfilment of the requirement of the University of South Africa for the degree of Master of Education. Pretoria: University of South Africa. 
Cole, G.A. (2004), Management Theory and Practice. $6^{\text {th }}$ Ed: Thomson Publication.

Cole, G.A. (2009), Personnel and Human Resources Management. $5^{\text {th }}$ Ed: Book Power.

Cooper, B. \& Green, P. (2105), Authentic Testing in Mathematics? The Boundary between Every day and Mathematical Knowledge in National Curriculum Testing in English Schools. Bishop, A.J: Routledge.

Creswell, J.W. (2007), Qualitative Inquiry and Research Design: Choosing Among Five Approaches. $2^{\text {nd }}$ Ed. Thousand Oaks, CA: Sage.

Herzberg, F. (1959), The Motivation to work. $2^{\text {nd }}$ Ed. New York: John Wiley and Sons.

Hosseini, S.A.R. (2013), Factors Affecting Employee Motivation. Management and Administrative Sciences Review. vol: 3, issue no. 4, pp.713-723.

Kumar, R. (2011), Research Methodology A Step-by-Step Guide for Beginners. Journal for Research Methods for Business \& Management.

Lock, G. (2008), Preparing Teachers for Rural Appointments: Lessons from Australia. The Rural Educator. vol.29, pp.24-30.

Lumley, E.J. et al (2011), Exploring the Job Satisfaction and Organisational Commitment of Employees in the Information Technology: Enxion.

Maicibi, A.N. (2004), The Applicability of Herzberg's Two-Factore Theoru on Junior NonAcademic Staff of Makerere University. Business Review. vol. 1, pp.43-44.

Marshall, C. \& Gretchen B. R. (1999), Designing qualitative research. 3 rd ed. London: Sage Publications.

McLeod, S. (2007), Maslow's Hierarchy of Needshttp: [Online] 14 July. Available from: htmlhttp://www.simplypsychology.org/maslow.html. [Accessed 27 August 2016].

Mills, A. J., Durepos, G. \& Wiebe, E. [Eds.] (2010), Encyclopedia of Case Study Research, Volumes I and II. Thousand Oaks, CA: Sage.

Peresuh, M. \& Nhundu, T. (1999), Foundations of Education for Africa. Harare: College Press.

Ployhart, R.E. \& Moliterno, T.P. (2011), Emergence of the Human Capital Resource: A Multilevel model. Academy of Management Review. vol. 36, no. 1, pp.127-150.

Public Services Regulations, 2000 (SI 1/2000), Zimbabwe: Government Printers.

Saunders, M., Lewis, P. \& Thornhill, A. (2012), Research Methods for Business Students. Pearson Education Ltd., Harlow.

Urdziková, J. \& Kiss, J. (2009), Motivation-A Way to Retain Key Employees. Institute of Industrial Engineering, University of Technology. Bratislava: Paulínska.

Wright, P. M. \& McMahan, G. C. (2011), 'Exploring Human Capital: Putting Human Back into Strategic Human Resource Management'. Human Resource Management Journal. vol. 21, no. 2, pp.93-104.

ZIMBABWE. Public Service Act Chapter 6:04. (1998), Harare: Government Printers.

Zvavahera, P. (2014), An evaluation of the effectiveness of performance management systems on service delivery in the Zimbabwean civil service. Journal of Management and Marketing Research. 